\title{
Nutritional requirements of energy, protein and macrominerals for maintenance and weight gain of young crossbred Nellore $\times$ Holstein bulls on pasture ${ }^{1}$
}

\section{Marlos Oliveira Porto², Mário Fonseca Paulino ${ }^{3}$, Sebastião de Campos Valadares Filho ${ }^{3}$, Edenio Detmann ${ }^{3}$, Jucilene Cavali ${ }^{2}$, Maykel Franklin Lima Sales ${ }^{4}$, Ériton Egidio Lisboa Valente $^{5}$, Victor Rezende Moreira Couto ${ }^{5}$}

\author{
${ }^{1}$ Research funded by CNPq and FAPEMIG \\ 2 DZO - Universidade Federal de Rondônia. \\ ${ }^{3}$ DZO - Universidade Federal de Viçosa. Researcher from INCT-CA. \\ ${ }^{4}$ Embrapa Rio Branco - AC. \\ ${ }^{5}$ DZO - Universidade Federal de Viçosa.
}

\begin{abstract}
The objective of this study was to estimate requirements of energy, protein and macrominerals of young Nellore/Holstein crossbreds bulls supplemented on pastures of Brachiaria decumbens Stapf. Thirty-five young bulls, at $8.53 \pm 0.18$ months of age and with initial body weight of $230.6 \pm 6.1 \mathrm{~kg}$ were used. Ten animals were slaughtered as reference, in different weight range, and the other animals were slaughtered at the end of the experimental period. For estimate of net energy requirements for weight, a regression equation between log of retained energy (RE) and log of empty body weight gain (EBWG) was constructed. Net requirements of $\mathrm{Ca}, \mathrm{P}, \mathrm{Mg}$, $\mathrm{Na}$ and $\mathrm{K}$ were determined by the equation $\mathrm{Y}^{\prime}=\mathrm{a} \cdot \mathrm{b} \cdot \mathrm{X}^{\mathrm{b}-1}$, in which $\mathrm{a}$ and $\mathrm{b}$ represent the intercept and the coefficient of equation of prediction of macrominerals in body content, respectively. Requirements of metabolizable energy for maintenance (MEm) were obtained from retained energy in function of metabolizable energy intake (MEI). The requirements of MEm of Nellore/Holstein crossbreds young bulls on pasture was $125 \mathrm{kcal} / \mathrm{EBW}^{0.75} / \mathrm{day}$. The efficiency of ME utilization for maintenance $\left(\mathrm{k}_{\mathrm{m}}\right)$ of grazing Nellore/Holstein crossbred young bulls was 0.58 and 0.24 for gain. The total metabolizable protein requirements for an animal with $400 \mathrm{~kg}$ and with average daily gain of $1.0 \mathrm{~kg}$, were $638.36 \mathrm{~g}$ /day. The dietetic requirements of Ca and P for an animal with $400 \mathrm{~kg}$ BW were 0.49 and $0.21 \%$ of DM, respectively. Daily metabolizable energy requirement for maintenance of grazing Nellore/Holstein crossbred young bulls was $11.6 \%$ greater than the values found for cattle in feedlot in Brazil $\left(112 \mathrm{kcal} / \mathrm{kg} \mathrm{EBW}^{0.75}\right)$.
\end{abstract}

Key Words: multiple supplements, net energy, supplementation, Zebu

\section{Introduction}

The Brazilian livestock is predominantly developed in production systems which use pasture as the main ingredient of the diet because it is a low cost way of producing milk and beef in the tropics.

The success of any cattle rearing system, either in feedlot or pasture, depends on the adequacy of the diet to the nutritional needs of animals. The nutritional plan shall be well designed inasmuch as the herd feeding is about $70 \%$ of the cost of production. However, the tables and equations on nutritional requirements and programs using them are based on information obtained from cattle raised in feedlot (NRC, 2000; Valadares Filho et al., 2006a).

CSIRO (2007) has recommended that the maintenance requirements for beef cattle raised on pasture be from 10 to $50 \%$, and in function of the distance traveled, the availability of pasture and slope of the terrain.
Some studies on nutritional requirements for cattle raised on pasture (Zervoudakis et al., 2002; Fregadolli, 2005; Moraes et al. 2009; Paixão, 2008; Sales et al. 2010; Sales et al., 2011) have been developed in Brazil, but the amount of information available is still considered small for the development of equations that are considered as reliable for use in diet formulation programs, especially regarding the supplementation of these animals.

The composition of the gain in supplemented animals may also interfere with the requirements of gain. Poppi \& Mclennan (1995) reported that supplementation increases the availability of metabolizable protein, the protein:energy absorbed ratio and energy retention, reducing metabolic heat production, and maintenance requirements. These factors may lead to differences in the rate of deposition of body tissues by changing the requirements for weight gain of animals.

The activity of growing and fattening of male crossbred Nellore/Holstein is a national reality, due to frequent use of 
Nellore bulls in cows producing milk, with some degree of Holstein breed, making it necessary to know the nutritional requirements of such animal reared in pasture.

Thus, the objective of this study was to evaluate body composition and nutritional requirements for maintenance and weight gain of Nellore/Holstein bulls raised on pastures, fed different levels of energy in multiple supplements during the rainy season.

\section{Material and Methods}

The experiment was conducted in the beef cattle sector in the Animal Science Department at Universidade Federal de Viçosa, located in Viçosa-MG, from July 5th, 2006 to April 11th, 2007.

Thirty-five crossbreed Nellore/ Holstein young bulls at $8.5 \pm 0.2$ months of age and with $230.6 \pm 6.1 \mathrm{~kg}$ were used in the experiment. Ten control animals were slaughtered in three different periods.

The 25 animals remaining were $14.9 \pm 0.25$ months of age and with $325 \pm 11.04 \mathrm{~kg}$, and they were divided into five plots of five animals each, according to a completely randomized design. The animals were grouped as follows: maintenance group and control, which were fed mineral mixture; and three groups fed supplements, formulated with different levels of energy, meeting approximately 10.0, 20.0 and $30.0 \%$ of total digestible nutrient requirements recommended by NRC (2000) for a 350-kg young bull with average daily gain of $1.0 \mathrm{~kg}$. Supplements were offered at $0.75,1.5$ and $2.25 \mathrm{~kg} /$ animal, containing 53.0, 27.0 and $18.0 \%$ crude protein (CP), respectively, aiming to provide $400 \mathrm{~g}$ of $\mathrm{CP} / \mathrm{animal} / \mathrm{day}$, meeting approximately $45.0 \%$ of CP requirement.

The experimental area consisted of five paddocks of 2.0 ha with Brachiaria decumbens Stapf., provided with covered drinking and feeding troughs. In addition to these animals, in the paddock (2.0 ha) for the animals of maintenance group, eleven more young bulls, with average weight of $185.0 \mathrm{~kg}$ were used to control forage availability, which ruled the permanence or removal of controlling animal in the paddocks.

The animals were relocated in the paddocks every 14 days, aiming at eliminating possible effects of paddocks on treatments, except for the maintenance animals, which remained in the same experimental area. Weighing and height measuring were performed at rump height of the animals every 28 days. The animals in the maintenance group along with the control animals were weighed every 14 days to monitor weight gain and the availability of forage in the paddock.

Supplements (Table 1) were provided daily at 10:00 p.m. in a common trough with two meters in length, to allow simultaneous access of animals.

Table 1 - Percentage composition of supplements on natural matter basis and chemical composition of the supplements and pasture

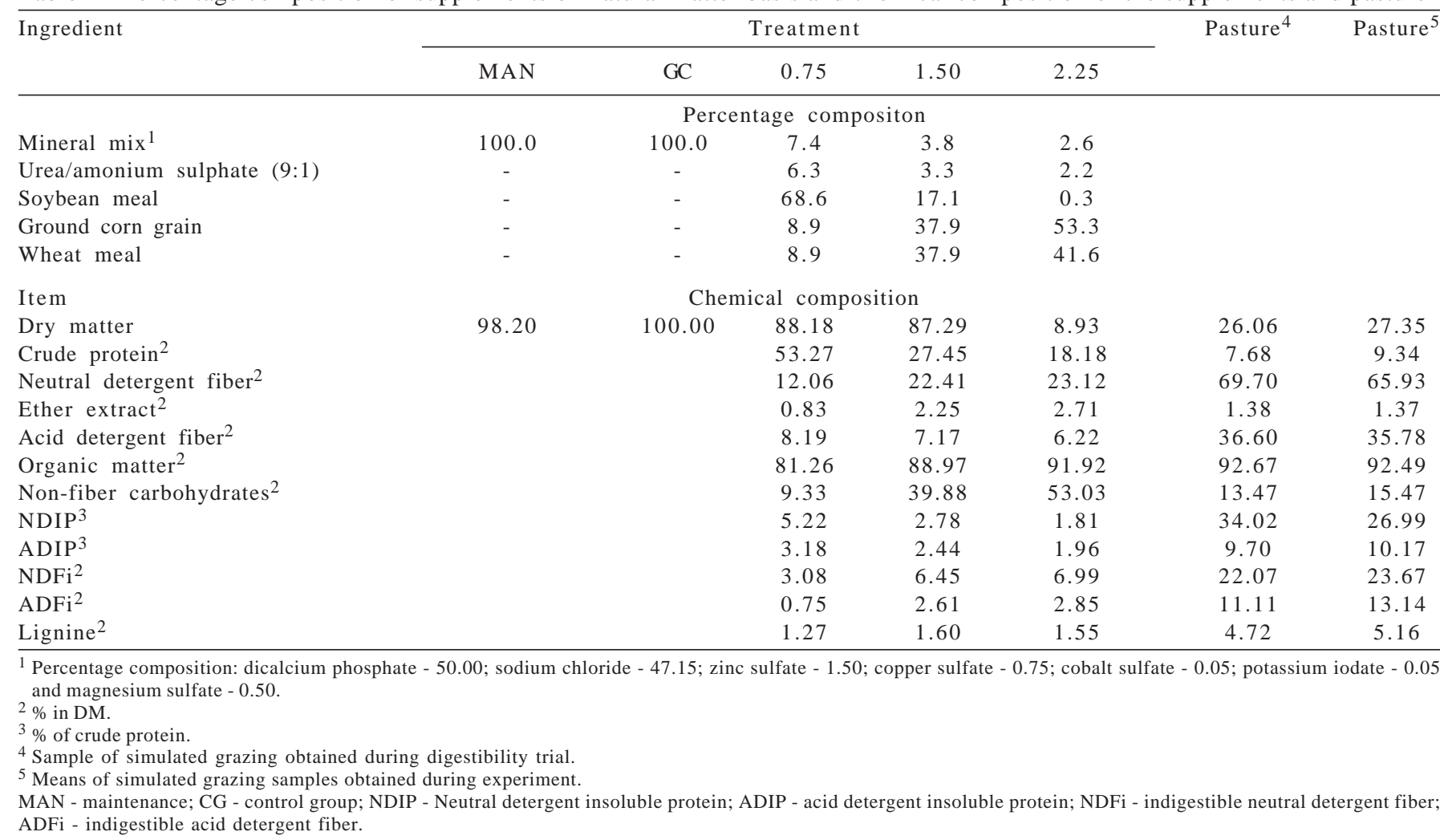


Pasture collections were carried out on the fourteenth day of each experimental period to evaluate the total availability of dry matter (DM), by cutting at $5 \mathrm{~cm}$ from the ground, in four areas of $0.5 \times 0.5 \mathrm{~m}$, randomly distributed in each experimental paddock. Then, potentially digestible DM (DMpd)/ha and the availability of DM of green leaf, dry leaf, green stem and dry stems/ha were quantified in each experimental paddock. Samples were weighed and oven-dried $\left(60^{\circ} \mathrm{C}, 72\right.$ hours).

Evaluation of the content of potentially digestible DM of pasture total was performed according to Paulino et al. (2006a), by using the following equation:

$D M p d=0.98(100-N D F)+(N D F-N D F i)$

All animals were submitted to a digestion trial on pasture for a period of ten days: the first seven days for adaptation of animals and stabilization of markers inflow as described by Titgemeyer et al. (2001).

To estimate the excretion of fecal DM (FE), chromic oxide was used as external marker as recommended by Smith \& Reid (1955), which was applied once daily (10 g/animal), packed in paper cartridge and introduced through an applicator directly into the esophagus of animals for nine consecutive days. After seven days of adaptation, stool samples of animals were collected on the eighth (4:00 p.m.), ninth (12:00 p.m.) and tenth (8:00 a.m.) days.

Calculation of fecal excretion was performed based on the ratio between the amount of marker supplied and its concentration in feces, according to the equation:

$\mathrm{FE}=(\mathrm{CrFo} / \mathrm{CrFe}) \times 100$

in which: $\mathrm{CrFo}=$ amount of supplied chromium (g) and $\mathrm{CrFe}=$ fecal chromium concentration (\% or g/kg).

To determine individual supplement intake (ISI), titanium dioxide was used at $10 \mathrm{~g} /$ animal, mixed with the supplement immediately before supply, according to procedure described by Valadares Filho et al. (2006b), following the same scheme of feces collection described for chromium oxide, through the equation:

$I S I=\left(\mathrm{FE} \times \mathrm{TiO}_{2} \mathrm{Fe}\right) / \mathrm{TiO}_{2} \mathrm{~S}$

in which: $\mathrm{TiO}_{2} \mathrm{Fe}$ and $\mathrm{TiO}_{2} \mathrm{~S}=$ concentration of titanium oxide in the feces and in the supplement, respectively.

Dry matter voluntary intake (DMI) was estimated by the ratio between fecal excretion and the internal marker indigestible acid detergent fiber (ADFi), obtained after 264 hours of incubation in situ (Casali et al., 2008), through the equation:

$S I=\{[(F E \times A D F i F e)-A D F i S] / A D F i F O R\}+D M S I$ in which: $A D F i F e=A D F i$ in the feces $(\mathrm{kg} / \mathrm{kg}) ; A D F i S=$ ADFi in the supplement (kg/day); $A D F i F O R=$ forage ADFi concentration $(\mathrm{kg} / \mathrm{kg})$ and $D M S I=$ dry matter supplement intake (kg/day).
After collection, samples of simulated grazing and feces were dried in a forced ventilation oven at $65^{\circ} \mathrm{C}$ for 72 hours, processed in a Willey type mill with $1.0-\mathrm{mm}$ sieve and then submitted for laboratory analyses.

Contents of crude protein and ether extract (EE) were estimated in samples of pasture and concentrates, according to Silva \& Queiroz (2002); neutral detergent fiber (NDF) was estimated by using amylase, making the appropriate corrections for protein and ash according to Mertens (2002) and acid detergent fiber (ADF) and lignin (sulfuric acid $72 \%$ ) were estimated according to the methods of Van Soest \& Robertson (1985). Levels of neutral detergent insoluble nitrogen (NDIN) and acid detergent insoluble nitrogen (ADIN) were estimated as described by Licitra et al. (1996).

Quantification of non-fiber carbohydrates (NFC) was performed according to Hall (2000):

$N F C=100-[(\% C P-\%$ urea $C P+\%$ urea $)+\% N D F a p+$ $\% E E+\% a s h]$

in which: NDFap = neutral detergent fiber corrected for ash and protein.

Nutrient digestibility was calculated from DM intake and fecal excretion, and metabolizable energy intake (MEI) was estimated from content of dietary total digestible nutrients (TDN).

Animals followed the protocol of slaughter divided into four stages; three stages were for control animals, and the last one for the other animals.

In the first stage, during the dry period and eight days after the start of the experiment on pasture, four animals at $8.0 \pm 0.4$ months of age and with $199.0 \pm 21.6 \mathrm{~kg}$ body weight were slaughtered.

In the second stage, in the early dry-rainy season, held on October 18th 2006, three animals at $11.6 \pm 0.18$ months and with $267.8 \pm 6.70 \mathrm{~kg}$ body weight were slaughtered.

In the third slaughter, carried out on January 9th 2007, during the rainy season, three other animals were slaughtered, with average age and body weight of $14.9 \pm 0.21$ months and $317.3 \pm 9.26 \mathrm{~kg}$, respectively, finishing the control slaughter.

In the fourth stage, the final slaughter of the 25 remaining animals were performed in scale manner at 83, 87, 94 and 96 days after the third slaughter: six animals slaughtered at a time, except for slaughter at 83 days, when seven animals were slaughtered. In each slaughter scale, one animal in each treatment was slaughtered, plus one or two animals at random, making a total of 25 animals in four consecutive scales of slaughter, which were at 17.9 months of average age and $400.6 \pm 12.3 \mathrm{~kg}$.

During slaughter, all constituents of the body (organs, viscera, blood, hide, head and limbs) were weighed and 
sampled for determination of empty body weight (EBW) and body composition of animals in different weight ranges. Data regarding the initial and intermediate slaughters were used to estimate initial body composition of the 25 animals which remained in the experiment.

Before slaughter, all animals were fasted for 14 hours to obtain the live weight at fasting. After slaughter, the gastrointestinal tract of each animal was weighed, emptied and washed, and its weight was to the organs and other body parts (carcass, head, hide, tail, feet and blood) for determination of empty body weight (EBW). The ratio between the EBW and body weight (BW) of animals at each slaughter, was used to estimate the initial EBW of the animals which remained in the experiment. Within each treatment, three animals were randomly selected to represent it, from which samples of the head, forelimb and hind limbs were taken for physical separation of soft tissue, bone and hide.

Blood samples were collected immediately after the section of the jugular vein of all animals, packed in glass container and placed in a forced ventilation oven for 72 hours at $60{ }^{\circ} \mathrm{C}$. Samples of industrial meat, liver, heart, kidneys, spleen, lungs, tongue, rumen, reticulum, omasum, abomasum, small intestine, large intestine, mesentery, internal fat, trimmings and tail were grouped by animal, processed and homogenized entirely in a 65-L cutter, from which a sample was taken, representing the organs and viscera.

The carcass of each animal was divided into two halves, which were weighed and then cooled in a cold chamber at $2.0^{\circ} \mathrm{C}$ for about 18 hours. After that, the right carcasses of 15 animals, 3 animals per treatment, were taken from the cold chamber and completely dissected, then they were separated into muscles, fat and bones, which were weighed later.

To estimate the body composition of the 10 other animals, a representative sample was collected from the left carcass of all slaughtered animals, corresponding to the section from the 9th to the 11th ribs, called $\mathrm{H}-\mathrm{H}$ section, for further dissection and prediction of the proportions of muscle, adipose and bone tissue, according to equations proposed by Hankins and Howe (1946):

Proportion of muscle tissue: $\hat{Y}=16.08+080 \times$

Proportion of adipose tissue: $\hat{Y}=3.54+0.80 \times$

Proportion of bone tissue: $\hat{Y}=5.52+0.57 \times$

in which: $x=$ percentage of components in $\mathrm{H}-\mathrm{H}$ section.

Muscle tissue and adipose tissue were ground and bone tissue was sawed into smaller pieces. A representative sample was taken from each component direct determination of protein and fat from the carcass.
After fresh samples were ground, they were processed according to procedure described by Paulino et al. (2004), to obtain the dry fat matter (FDM), and then pre-defatted dry matter (DDM). The fat removed in the pre-defattening was calculated as the difference between the FDM and DDM, whose result was added to the result obtained for the residual ether extract in the pre-defattening dry matter (PDDM) to determine the total fat content. From the knowledge of contents of protein, ether extract and macrominerals (Ca, P, Na, K and Mg) in PDDM and weight of the sample submitted to pre-defattening, their levels were determined in natural matter basis.

Then, samples were processed in a ball mill for further measurements of total nitrogen, ether extract and macro minerals (Ca, P, Na, K and Mg) as recommended by Silva \& Queiroz (2002). The protein content was obtained by multiplying the content of total nitrogen concentration by factor 5.88 as suggested by Baldwin (1995).

For animals which did not have their right carcass dissected, the body content of fat, protein and macrominerals ( $\mathrm{Ca}, \mathrm{P}, \mathrm{Na}, \mathrm{K}$ and $\mathrm{Mg}$ ) were determined in function of the percentage of concentrations in organs, viscera, hide, blood, head, feet and constituents of fat, muscle and bones of $\mathrm{H}-\mathrm{H}$ section.

Mineral solution to determine the mineral macroelements was prepared by nitro-perchloric digestion. After proper dilution, $\mathrm{P}$ content was estimated by colorimetry, contents of $\mathrm{Ca}$ and $\mathrm{Mg}$ by atomic absorption spectrophotometer, and the $\mathrm{Na}$ and $\mathrm{K}$ by flame spectrophotometer.

The estimate of body energy was obtained from the body levels of fat and protein and their caloric equivalents, according to the equation recommended by the ARC (1980): $E C=5.6405 x+9.3929 Y$, in which EC = energy content (Mcal); $\mathrm{x}=$ body content $(\mathrm{kg})$; $\mathrm{Y}=$ body fat $(\mathrm{kg})$.

The contents of fat, protein, energy and macro minerals (Ca, P, Na, K and Mg) retained in the body of animals of each treatment and all treatments together were estimated by regression equations of logarithm of body content of protein, fat, energy and macrominerals in function of the logarithm of EBW, according to the ARC (1980), as the following model:

$\mathrm{Y}=\mathrm{a}+\mathrm{bx}+\mathrm{e}$

in which: $\mathrm{Y}=$ total content of protein $(\mathrm{kg})$, fat $(\mathrm{kg})$, macrominerals (kg) and energy (Mcal) retained in the empty body; $\mathrm{a}=$ coefficient; $\mathrm{b}=$ exponent or growth rate in content of fat, energy and macrominerals in function of EBW; $\mathrm{x}=\mathrm{EBW} ; \mathrm{e}=$ random error.

For each treatment, the equations were constructed by adding the values related to control animals. 
By deriving the prediction equations of body content of protein, energy and macro minerals in function of the logarithm of EBW, the equation for predicting the content of protein, energy and macro minerals per kg of EBW gain, corresponding to the net energy requirements to $1.0 \mathrm{~kg}$ gain of EBW was obtained, from the equation of the following type:

$Y^{\prime}=a \cdot b \cdot x^{b-1}$

in which: $Y^{\prime}=$ fat content in the gain or net requirements of protein, energy and macrominerals; $a$ and $b=$ intercept and regression coefficient of the equations for predicting body content of fat in the gain, net requirements of protein, energy and macro minerals, respectively; $\mathrm{x}=\mathrm{EBW}(\mathrm{kg})$.

For the conversion of live weight (LW) into EBW, within the range of weights included in this research, the relationship between EBW and LW of the 35 animals used in the experiment was calculated. For conversion of requirements for empty body weight gain (EBWG) into requirements for LWG, the factor 0.9071 obtained from experimental data was used.

The metabolizable protein requirements for maintenance (MPm) and gain (MPg) and crude protein requirements were obtained according to the NRC (2000).

To estimate the net energy requirements for weight gain (NEg) for animals of different empty body weight gains and for different ranges of empty weight, the ratio of retained energy (RE) in function of metabolic EBW and EBWG was used according to the NRC (2000):

$R E($ Mcal/day $)=a \cdot E B W^{0.75} \cdot E B W G^{b}$

The fasting heat production or the net requirement for maintenance energy (NEm) was estimated as the antilogarithim of the intercept of the equation obtained by linear regression between the logarithm of heat production (CP) and metabolizable energy intake (MEI) of animals in the maintenance group and those supplemented according to Lofgreen \& Garret (1968).

The values of ME in the diet were calculated considering that $1 \mathrm{~kg}$ of TDN is equal to $4.409 \mathrm{Mcal}$ of digestible energy (DE) and $1 \mathrm{Mcal}$ of DE is equal to $0.82 \mathrm{Mcal}$ of ME (Coelho da Silva \& Leão, 1979; NRC, 2000).

Use efficiency of metabolizable energy for maintenance $\left(\mathrm{k}_{\mathrm{m}}\right)$ was estimated from the relationship between contents of net energy for maintenance and $\mathrm{ME}$ of the diet, according to Garrett (1980) and use efficiency of metabolizable energy for weight gain $(\mathrm{kg})$ was estimated as the slope of the linear regression between retained energy and metabolizable energy intake, according to the NRC (2000) and Ferrell \& Jenkins (1998).

Metabolizable energy requirements for maintenance were estimated through regression equation obtained from the retained energy ( $\mathrm{kcal} / \mathrm{kg}$ of $\mathrm{EBW}^{0.75}$ ) and metabolizable energy intake ( $\mathrm{kcal} / \mathrm{kg}$ of $\mathrm{EBW}^{0.75}$ ) (Valadares Filho et al., 2006c).

Metabolizable energy requirement for gain was obtained by the relationship between net energy requirement for gain and UEME. The requirement of TDN was calculated by dividing the ME requirement by 0.82 , resulting in the requirement of digestible energy and then dividing this requirement by 4.409 .

Net protein requirements for gain were obtained by multiple linear regression of retained protein (RP, g/day) in EBWg (kg/day) and retained energy (RE, Mcal/day), according to the equation:

$P R(g /$ day $)=c+d \times G P C V Z+e \times E R$

in which: $\mathrm{c}=$ regression equation intercept; $\mathrm{d}=$ regression coefficient for empty body weight gain; e = regression coefficient for retained energy.

Metabolizable protein requirements for maintenance (MPm) and gain (MPg) and crude protein requirement were obtained according to the recommendations of Valadares Filho et al. (2006d), adopting the value of metabolizable protein requirements for maintenance $4.0 \mathrm{~g} / \mathrm{kg} \mathrm{EBW}^{0.75}$ suggested by these authors.

To estimate the maintenance requirement of each mineral macroelement and then add them to the requirements for gain, in order to obtain the total dietary requirements, recommendations of the ARC (1980) and NRC (2000) were adjusted for endogenous losses of Ca, P, $\mathrm{Mg}, \mathrm{Na}$ and $\mathrm{K}$ and the bioavailability of these elements in the feeds (Table 2).

Table 2 - Total endogenous losses and bioavailability of Ca, P, $\mathrm{Mg}$, Na and $\mathrm{K}$

\begin{tabular}{|c|c|c|}
\hline Element & Total endogenous loss & Bioavailability (\%) \\
\hline $\mathrm{Ca}$ & $15.4 \mathrm{mg} / \mathrm{kg} \mathrm{BW} \mathrm{BW}^{1}$ & $50^{1}$ \\
\hline $\mathrm{P}$ & $16.0 \mathrm{mg} / \mathrm{kg} \mathrm{BW}^{1}$ & $68^{1}$ \\
\hline Mg & $3.0 \mathrm{mg} / \mathrm{kg} \mathrm{BW}{ }^{1}$ & $17^{2}$ \\
\hline $\mathrm{Na}$ & $6.8 \mathrm{mg} / \mathrm{kg} \mathrm{BW} \mathrm{BW}^{1}$ & $91^{2}$ \\
\hline K & $\begin{array}{l}\text { Fecal }-2.6 \mathrm{~g} / \mathrm{kg} \text { intaked } \mathrm{DM}^{2} \\
\text { Urinary }-37.5 \mathrm{mg} / \mathrm{kg} \mathrm{BW}^{2} \\
\text { Salivar }-0.7 \mathrm{~g} / 100 \mathrm{~kg} \mathrm{BW}^{2} \\
\text { Through the skin }-1.1 \mathrm{~g} / \mathrm{day}^{2}\end{array}$ & $100^{2}$ \\
\hline
\end{tabular}

${ }^{1}$ Data obtained by NRC (2000).

2 Data obtained by ARC (1980)

BW - body weight; DM - dry matter.

\section{Results and Discussion}

The average availability of total dry matter availability (TDM) and potentially digestible dry matter (DMpd) was 4.53 and $3.15 \mathrm{t} / \mathrm{ha}$ and 2.56 and $1.63 \mathrm{t} / \mathrm{ha}$ in the paddocks for 
the animals in performance and those in weight maintenance, respectively (Figures 1 and 2).

It can be observed that there was a sharp drop in the availability of all components of the pasture in the paddock where the animals were in weight maintenance. This was due to higher grazing pressure, performed with the use of animals controlling the availability which were used.

According to Brosh et al. (2006), maintenance energy of cattle raised on pasture is affected by many factors besides grazing activity, and many of them are interdependent. The cost of maintenance of grazing animals may be from 8.0 to $30 \%$ higher than that of animals in feedlot, and this variation is dependent on the characteristics of the pasture

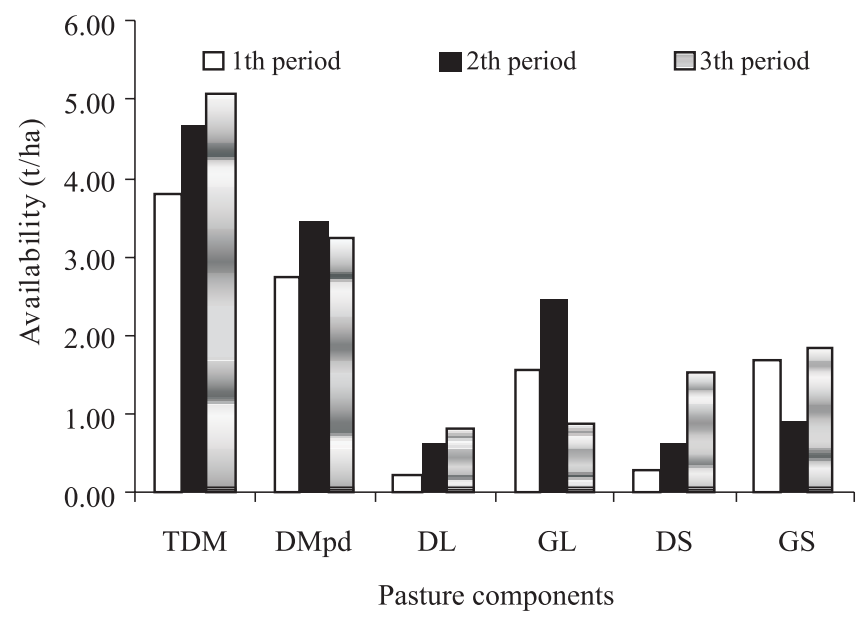

Figure 1 - Dry matter total availability (TDM) and potentially digestible dry matter (DMpd), dry leaf (DL), green leaf (GL), dry stem (DS) and green stem (GS) of the pasture, for performance animals.

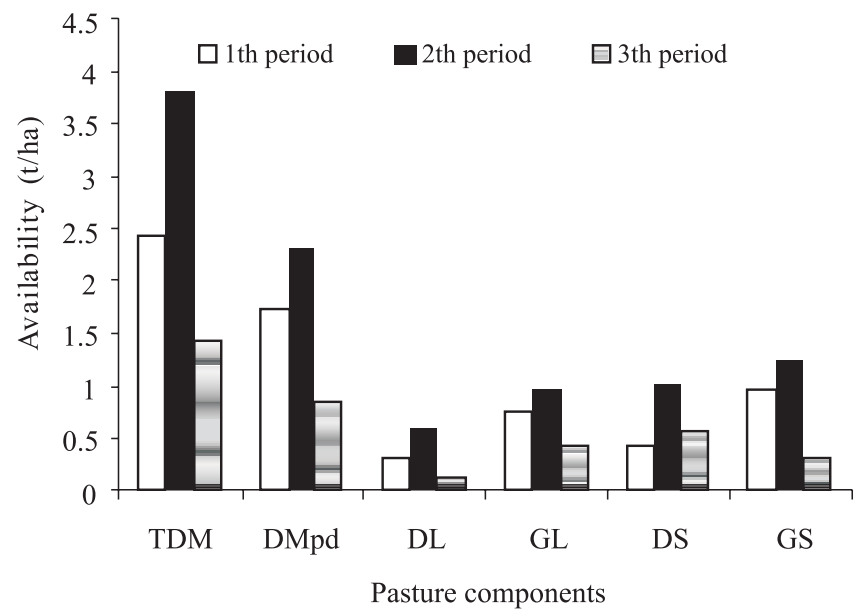

Figure 2 - Dry matter total availability (TDM) and potentially digestible dry matter (DMpd), dry leaf (DL), green leaf (GL), dry stem (DS) and green stem (GS) of the pasture, for animals at weight maintenance.
(DiMarco \& Aello, 2001). Therefore, forage availability at quality and quantity to the animal is what is going to dictate higher or lower energy use for maintenance in relation to their use for production.

The ratio of 0.9071 obtained for the estimation of EBW from the BW of the animals was similar to the 0.891 recommended by the NRC (2000), and the 0.8960 , by Valadares Filho et al. (2006c), although these relationships had been obtained for animals in feedlot. When comparing the ratios obtained in this study with those used with grazing animals, data from this study are numerically superior to those found by Zervoudakis et al. (2002), Fregadolli (2005) and Moraes et al. (2009), who reported values of $0.8575 ; 0.8746$ and 0.8877 , respectively, although close to the value of 0.8997 found by Sales (2008), who carried out experiments in conditions similar to this research.

The determination of EBW and EBWG is important to obtain the nutritional requirements of energy, protein and minerals for animals within several weight ranges and weight gain, unlike BW and BWG, which have, as part of the composition, the gastrointestinal tract, which is dependent on the individual and on the diet received by this animal. According to Valadares Filho et al. (2006c), empty body composition is a determinant of energy and protein requirements for weight gain inasmuch as they are estimated from the energy and protein retained in the body. These authors emphasized that the differences found in the composition of weight gain of empty body explain the increased energy requirements for weight gain of early animals compared with late animals.

For conversion of the requirements for EBWG into requirements for body weight gain (BWG), the following relationship was obtained:

EBWG $=0.886 \times$ BWG, which is a value lower than that recommended by Valadares Filho et al. (2006c), which was 0.933 , found for animals raised in feedlots. This is caused by the greater filling of the gastrointestinal tract of cattle raised on pasture because of the greater participation of the forage fraction in the diet of these animals when compared with those obtained by Valadares Filho et al. (2006c).

Increasing contents of fat and consequently of retained energy, as BW increased from 200 to $400 \mathrm{~kg}$, was observed (Table 3). When the energy no limited the growth of the animals, the proportion of fat in EBW increased in response with increment of the body weight (NRC, 2000).

There was increase in body fat content (from 15.87 to $38.39 \mathrm{~kg}$ ), energy (from 345.02 to $746.02 \mathrm{Mcal}$ ) and protein (from 34.57 to $67.93 \mathrm{~kg}$ ), equivalent to increases of 141.90 , 116.22 and $96.50 \%$, respectively, with the increase in BW of animals from 200 to $400 \mathrm{~kg}$ (Table 4). Similarly, the 
Table 3 - Parameters of allometric equations of the contents of fat, protein, and macrominerals ( $\mathrm{Ca}, \mathrm{P}, \mathrm{Na}, \mathrm{K}$ and $\mathrm{Mg}$ ) and energy (Mcal) in the empty body in function of logarithm of EBW (kg) of the animals

\begin{tabular}{lccc}
\hline Component & \multicolumn{2}{c}{ Parameters $^{1}$} & \\
\cline { 2 - 3 } & Coefficient (a) & Exponent (b) & $\mathrm{r}^{2}$ \\
\hline Protein & 0.217499 & 0.974555 & 0.98 \\
Fat & 0.021049 & 1.273948 & 0.80 \\
Energy & 1.059043 & 1.112562 & 0.94 \\
Calcium & 0.039886 & 0.858823 & 0.61 \\
Phosphorous & 0.012534 & 0.880299 & 0.65 \\
Sodium & 0.001968 & 0.934682 & 0.86 \\
Potassium & 0.001436 & 1.047958 & 0.95 \\
Magnesium & 0.000656 & 0.929127 & 0.74 \\
\hline
\end{tabular}

${ }^{1} \mathrm{a}=$ coefficient; $\mathrm{b}=$ exponent or growth rate in content of fat, energy and macrominerals in function of EBW.

concentrations of fat, in $\mathrm{g} / \mathrm{kg}$ of EBW, and energy in Mcal $/ \mathrm{kg}$ of EBW increased by $20.91 \%$ and $8.02 \%$, respectively, whereas protein $\mathrm{g} / \mathrm{kg}$ of EBW decreased by $1.75 \%$, with the increase in BW (Table 4), showing the contribution of fat to the increase in the energy content in EBW, unlike protein.

When the contents of protein $(\mathrm{kg})$ are divided by the sum of the contents of fat and protein $(\mathrm{kg})$ for animals of 200 or $400 \mathrm{~kg}$ of BW, it is found that this ratio rises from 0.69 to 0.64 , confirming the smaller participation of protein in body composition. This behavior can be attributed to the deceleration of muscle growth as BW increases, leading to a smaller protein deposition and increased fat deposition, which was also found by Berg \& Butterfield (1976).

Animals presented low fat content, only $134.78 \mathrm{~g} / \mathrm{kg}$ of EBW at $400 \mathrm{~kg} \mathrm{BW}$. This may be because the animals were not castrated (production of hormone testosterone), thereby not reducing protein synthesis so markedly, increasing muscle mass, especially in the fore part, because the animals had not reached sexual maturity yet at only 18 months of age, which may explain the slow rate of reduction in protein content (g/kg EBW).

The composition of weight gain in supplemented animals may also interfere with gain requirements. Poppi \& Mclennan (1995) stated that supplementation increases the availability of metabolizable protein, absorbed protein:energy ratio and energy retention, reducing the metabolic heat production and maintenance requirements. These factors may lead to differences in the rate of deposition of body tissues by changing the gain requirements of the animals.

Requirement of net energy for maintenance (NEm) was $71.9 \mathrm{kcal} / \mathrm{kg} \mathrm{EBW}^{0.75} /$ day (66.88 kcal $/ \mathrm{kg} \mathrm{BW}^{0.75}$ ), close to the value of $71.2 \mathrm{kcal} / \mathrm{kg} \mathrm{EBW}^{0.75} /$ day found by Chizzotti et al. (2007) for non-castrated and castrated males and females 1/2 Red Angus /Nellore in feedlot system, and also close to the value of $71.30 \pm 12.69 \mathrm{kcal} / \mathrm{kg} \mathrm{EBW}^{0.75}$ found by Silva et al. (2002) for Nellore animals in feedlot. Because animals used by Chizzotti et al. (2007) were $1 / 2$ Bos taurus/Bos indicus, which had already been intensively selected for weight gain, they would have a greater maintenance requirement. Therefore, this could explain the reason why these animals, even in feedlot system, would have NEm requirements similar to that of Nellore/Holstein animals raised on pastures.

NRC (2000) suggests net energy for maintenance 10\% lower for Zebu animals, when compared with the Taurus. According to Sainz et al. (2006), there are studies reporting that lower post-mortem muscle proteolysis of Zebu animals, due to a greater activity of calpastatin, indicate that the protein turnover of Zebu animals is smaller than Taurus, which contribute for them to present smaller energy consumption inasmuch as the recycling body protein is a major component of energy expenditure involved in maintenance.

The value of NEm of this experiment was 3.36\% higher than the value of $69.33 \mathrm{kcal} / \mathrm{kg} \mathrm{EBW}^{0.75}$ found by Moraes et al. (2009). Valadares Filho et al. (2006c) suggested a requirement of net energy for maintenance of Zebu animals in Brazil of $78.5 \mathrm{kcal} / \mathrm{EBW}^{0.75}$, a value $9.5 \%$ higher than that found in this study. Boin (1995), analyzing three experiments in which non-castrated Nellore animals were used, obtained NEm values ranging from 69.8 to $78 \mathrm{kcal} / \mathrm{EBW}^{0.75}$.

The requirement of metabolizable energy for maintenace found by the intercept of the equation, obtained in function of the regression of RE by metabolizable energy intake, was $124.72 \mathrm{kcal} / \mathrm{kg} \mathrm{EBW}^{0.75}$, which is close to the $118 \mathrm{kcal} / \mathrm{kg}$ EBW $^{0.75}$ obtained by Tedeschi et al. (2002), for non-

Table 4 - Body content estimate for fat and energy in grazing Nellore/Holstein crossbred cattle

\begin{tabular}{lcccccc}
\hline BW $(\mathrm{kg})$ & Fat $(\mathrm{kg})$ & Fat $(\mathrm{g} / \mathrm{kg}$ EBW) & Energy $(\mathrm{Mcal})$ & Energy $(\mathrm{Mcal} / \mathrm{kg}$ EBW) & Protein $(\mathrm{kg})$ & Protein $(\mathrm{g} / \mathrm{kg}$ EBW) \\
\hline 200 & 15.87 & 111.47 & 345.02 & 2.12 & 34.57 & 185.69 \\
250 & 21.09 & 118.49 & 442.24 & 2.17 & 42.69 & 184.64 \\
300 & 26.61 & 124.56 & 541.69 & 2.21 & 51.32 & 183.78 \\
350 & 32.38 & 129.94 & 643.03 & 2.25 & 59.64 & 183.06 \\
400 & 38.39 & 134.78 & 746.02 & 2.29 & 67.93 \\
\hline
\end{tabular}

BW - body weight. 
castrated Nellore males, $11.61 \%$ higher than the value of $112 \mathrm{kcal} / \mathrm{kg} \mathrm{EBW}^{0.75}$ found for non-castrated Nellore males in feedlot by Valadares Filho et al. (2010), showing that the energy requirements for grazing cattle is superior to animals raised in feedlot.

An energy requirement for maintenance $10-20 \%$ higher for animals at good grazing conditions was suggested when comparing them with animals reared in feedlot (CSIRO, 2007). The size of the paddock (2 ha), could have contributed to lower energy requirement of animals, that is, they spent less time to reach the drinking and feeding troughs and pasture, contrarily to situations of extensive systems, in which the animals have to complete long distances to have access to pasture and water, requiring up to $50 \%$ more energy (CSIRO, 2007) compared with animals in feedlot.

Use efficiency of metabolizable energy for maintenance $\left(\mathrm{k}_{\mathrm{m}}\right)$ was 0.58 for a diet with $2.10 \mathrm{Mcal} / \mathrm{kg} \mathrm{DM}$; the value of $\mathrm{k}_{\mathrm{m}}$ is $7.94 \%$ lower than the $0.63 \mathrm{~km}$ found by Valadares Filho et al. (2006c). Because the value of $\mathrm{k}_{\mathrm{m}}$ can vary in function of energy concentration of diet, these differences observed in relation to the literature can be attributed to the higher energy concentration of the diets used in feedlot compared with pasture-based diets.

Metabolizable energy for maintenance increased by 68.34\% (Table 5), whereas live weight of the animal increased by $100.00 \%$ (from 200 to $400 \mathrm{~kg} \mathrm{BW}$ ), showing that the

Table 5 - Daily requirements of metabolizable energy (MEm) and digestible energy (DEm), expressed in Mcal, of total digestible nutrient (TDNm, in $\mathrm{kg}$ ) and metabolizable protein (MPm, in g) for maintenance of crossbreed cattle Nellore/Holstein, in function of body weight (BW, in kg)

\begin{tabular}{ccccc}
\hline BW & MEm & DEm & TDNm & MPm $^{1}$ \\
\hline 200 & 6.16 & 7.52 & 1.705 & 212.73 \\
250 & 7.29 & 8.89 & 2.016 & 251.49 \\
300 & 8.36 & 10.19 & 2.311 & 288.34 \\
350 & 9.38 & 11.44 & 2.595 & 323.68 \\
400 & 10.37 & 12.64 & 2.868 & 357.77 \\
\hline
\end{tabular}

${ }^{1} \mathrm{MPm}=4.0 \times \mathrm{PV}^{0.75} ; \mathrm{EBW}=\mathrm{LW} * 0.9071$. energy cost for maintenance of a smaller animal is relatively higher due to increased metabolic activity and surface/ volume ratio, which influences heat production, and consequently, energy expenditure of the animal. In addition, the relationship between digestive tract and liver/body weight decreases as the weight increases, and these organs account for 40 to $45 \%$ of the energy metabolism of cattle under normal conditions, with a metabolism six times more intense than the whole body (Reynolds et al., 1992).

The following equation was obtained for calculation of $\mathrm{NEg}: \mathrm{RE}=0.0414 \times \mathrm{EBW}^{0.75} \times \mathrm{EBWG}^{1.3034}\left(\mathrm{R}^{2}=59.6\right)$.

Use efficiency of metabolizable energy for gain $(\mathrm{kg})$ was $0.24\left(\mathrm{RE}=0.242 \times \mathrm{MEI}-30.29, \mathrm{R}^{2}=0.52\right)$, about $31.42 \%$ lower than the value of $35 \%$ found by Valadares Filho et al. (2006b) for animals with weight gain below $1.0 \mathrm{~kg} /$ day, a situation similar to this study, in which weight gains did not exceed this value. The lowest kg value may have been due to low concentration of energy on the diets for the animals. Sales (2008), working in situations similar to the present study found a value of $\mathrm{kg}$ of $29 \%$. Silva et al. (2002) found values of kg which ranged from $27 \%$ to $37 \%$ for diets with TDN of 62.49 and $75.55 \%$, respectively, which also shows the lowest kg for less energy diets.

The requirements of energy and protein for gain increased (Table 6) with increment of body weight. This behavior can be attributed to the deceleration of bone tissue growth as BW increases.

Net protein for gain (NPg) was obtained by the following equation: $R P(g /$ day $)=-14.50320+2.38594 R E(\mathrm{Mcal} /$ day $)$ +164.2072 EBWG $(\mathrm{kg} /$ day $),\left(\mathrm{R}^{2}=0.67\right)$. Silva et al. $(2002)$ found an equation for crossbred animals with positive coefficient of inclination, which results in increased RP, $\mathrm{RP}=31.4045+5.632 \times \mathrm{RE}+107.039 \times \mathrm{SWG}\left(\mathrm{R}^{2}=0.50\right)$, which reinforces the idea that RP can increase also when RE is increased per kg of EBW. Perhaps because animals in this study are non-castrated, they showed greater efficiency in protein metabolism.

Metabolizable energy (MEg) and metabolizable protein (MPg) for gain increased $54.47 \%$ and $30.17 \%$, respectively, as BW of the animals increased from 200 to $400 \mathrm{~kg}$, showing

Table 6 - Daily requirements of metabolizable energy (MEm), digestible energy (DEm), requirements of TDNg (kg/kg EBWG) and metabolizable protein (MPg) for maintainane of crossbreed cattle Nellore/Holstein, in function of body weight (BW, in kg)

\begin{tabular}{|c|c|c|c|c|}
\hline BW (kg) & MEg (Mcal/kg EBWG) & DEg (Mcal/kg EBWG) & TDNg (kg/kg EBWG) & $\operatorname{MPg}^{1}(g / k g$ EBWG) \\
\hline 200 & 9.16 & 10.26 & 2.33 & 221.23 \\
\hline 250 & 9.94 & 12.13 & 2.75 & 242.47 \\
\hline 300 & 11.40 & 13.90 & 3.15 & 267.83 \\
\hline 400 & 14.15 & 17.25 & 3.91 & 287.98 \\
\hline
\end{tabular}

${ }^{1}$ Net requirement/0.492 for EBW>300 kg; Net requirement $/(83.4-(0.114 \times \mathrm{EBW}))$ for EBW $\leq 300 \mathrm{~kg}$ 
that there was greater participation of fat in the composition of weight gain when compared with the protein, although non-castrated males deposit more lean tissue in the body than castrated males and females (Vandewert et al., 1985; Berg \& Butterfield, 1976). The value of $242.47 \mathrm{~g} / \mathrm{kg}$ EBWG/day of MPg, for 250-kg LW animals was 6.14\% lower than the $257.36 \mathrm{~g} / \mathrm{kg}$ EBWG/day found by Sales et al.(2010), working in similar conditions. While these authors observed an increase of $8.0 \%$ in requirement for MPg (from 200 to $350 \mathrm{~kg}$ BW), in the present experiment, this increase was $18.19 \%$, but when there was a change in the requirement of MPg of an animal from 350 to $400 \mathrm{~kg}$ of BW, the increase was only $0.49 \%$, whereas the increase in requirement for MEg was $10.55 \%$. The information mentioned above suggests energy requirement increasing more intensely than protein requirement, a result of the change in composition of gain, which tends to accumulate more fat over protein.

The TDN daily requirements are higher by approximately $30.5 \%$ for animals with 250 and $400 \mathrm{~kg} \mathrm{BW}$ (Table 7) compared with the one proposed in BR - Corte (Valadares Filho et al., 2006c). About 26 percentage units of this increase are due to the lower values of $\mathrm{k}_{\mathrm{m}}$ and $\mathrm{kg}(0.58 \mathrm{vs}$. $0.63 ; 0.24$ vs. 0.35 , respectively), making the requirements for ME for maintenance and weight gain greater and, hence the values of TDN, which confirms the greater requirements of animals raised on pasture estimated by the CSIRO (2007).

Requirements of rumen-undegradable protein (RUDP) were reduced from 21.07 and $12.71 \%$ (\% of CP), respectively, for animals with 200 and $400 \mathrm{~kg}$, which allows to infer that animals, especially in the finishing stage, need little RUDP, as noted by Sales et al. (2008), who used levels of urea in multiple supplements for animals at this stage of production, on deferred pasture, and found that urea can be used to replace soybean meal, for gains up to 600 grams/day.
Reduction in the requirements of CP (\% DM) when related to total protein requirements for maintenance and gain with DM intake (Table 7) was observed, showing that more intense increases in the requirements are related to the need for energy (Tables 4, 5, 6 and 7) and as the BW of the animal increases. Values of CP (\% DM) for animals with 200 to $400 \mathrm{~kg}$ reported in this study are within the recommended by Lazzarini et al. (2009), so increase in the rates of digestion of potentially digestible neutral detergent fiber might occur; another indication that the values presented in this study can be used safely.

Total dietary requirements of $\mathrm{Ca}, \mathrm{P}, \mathrm{Mg}, \mathrm{Na}$ and $\mathrm{K}$ for animals gaining $1 \mathrm{~kg}$ of EBW (Table 8 ) were estimated by using the average coefficients of true absorption recommended by the NRC (2000) for Ca and P and the ARC (1980) for Mg, $\mathrm{K}$ and $\mathrm{Na}$ (Table 2) and estimates of net requirements for maintenance and gain (Table 8).

Contents of macrominerals (g/kg EBW) decreased as BW increased, except for K content (Table 8). As animals were aging, rates of deposition of macromineral reduce inasmuch as most of the mineral content, 99,80 and $70 \%$ of $\mathrm{Ca}, \mathrm{P}$ and $\mathrm{Mg}$, respectively, are found in the bone tissue (AFRC, 1991; Coelho da Silva, 1995; NRC, 2000). However, $\mathrm{K}$ and $\mathrm{Na}$ are present mainly in the intra and extracellular fluids, respectively (Paulino et al., 2006b).

The content of Ca was reduced by $9.31 \%$ when the body weight ranged from 200 to $400 \mathrm{~kg}$ (Table 8). Silva et al. (2002) found value of $15.85 \mathrm{~g} / \mathrm{kg} \mathrm{EBW}$ for $\mathrm{F}_{1}$ animals (European $\times$ Zebu) with $250 \mathrm{~kg}$ body weight, close to the value of $15.93 \mathrm{~g} / \mathrm{kg}$ EBW found in this study.

The amount of $\mathrm{P}$ decreased as body weight increased (Table 8) inasmuch as it has a positive relationship with $\mathrm{Ca}$ deposited in the body of the animal, and the value of 5.45 for animals with $400 \mathrm{~kg}$ of BW is close to the value of $5.40 \mathrm{~g} / \mathrm{kg}$

Table 7 - Requirements of total metabolizable protein (MPt), degradated in the rumen (DRP), protein non-degrataed in the rumen (RUDP), crude protein (CP) and total digestible nutrients (TDN), for mainatance and weight gain (1.0 kg of BW) for Nellore/ Holstein crossbred cattle in function of the body weight (BW)

\begin{tabular}{|c|c|c|c|c|c|c|c|}
\hline \multirow[t]{2}{*}{ BW (kg) } & \multicolumn{2}{|c|}{$\mathrm{TDN}^{1}$} & \multirow[t]{2}{*}{ MPt (g/day) ${ }^{2}$} & \multirow[t]{2}{*}{ DRP (g/day) ${ }^{3}$} & \multirow[t]{2}{*}{ RUDP (g/day) ${ }^{4}$} & \multirow[t]{2}{*}{ CP (g/day) ${ }^{5}$} & \multirow[t]{2}{*}{$\mathrm{CP}(\% \mathrm{DM})^{6}$} \\
\hline & (kg/day) & $\%$ of DM & & & & & \\
\hline 200 & 3.76 & 77.32 & 428.31 & 501.78 & 133.96 & 635.74 & 13.05 \\
\hline 250 & 4.45 & 75.80 & 487.75 & 593.19 & 135.13 & 728.33 & 12.40 \\
\hline 300 & 5.10 & 74.24 & 549.13 & 680.12 & 142.54 & 822.65 & 11.96 \\
\hline 350 & 5.73 & 72.73 & 602.91 & 763.47 & 142.86 & 906.33 & 11.50 \\
\hline 400 & 6.33 & 71.31 & 638.36 & 843.89 & 122.84 & 966.73 & 10.88 \\
\hline
\end{tabular}

$1 \mathrm{TDN}=\mathrm{ME} / 0.82 / 4.409$

${ }^{2} \mathrm{MPt}=\mathrm{MPm}+\mathrm{MPg}$.

$3 \mathrm{DRP}=120(\mathrm{~g} / \mathrm{kg} \mathrm{TDN}) \times 1.11$

${ }^{4}$ RUDP $=($ MPTotal $-(\mathrm{PDR} / 1.11 \times 0.64)) / 0.8$

${ }^{5} \mathrm{CP}=\mathrm{DRP}+\mathrm{RUDP}$.

${ }^{6}$ DMI $(\mathrm{kg} /$ day $)=-2.40011+0.02006 \times$ average BW $+4.81946 \times$ ADG $-1.51758 \times$ ADG $^{2}$, equation proposed in BR-Corte $($ Valadares Filho et al., 2006d). 
Table 8 - Total net requirements and net requirements for gain and maintenance (g/day and \% DM) for macrominerals, calcium (Ca), phosphorus $(\mathrm{P})$, sodium $(\mathrm{Na})$, potassium $(\mathrm{K})$ and magnesium $(\mathrm{Mg})$, in function of the body weight

\begin{tabular}{|c|c|c|c|c|c|c|}
\hline Weight & $\mathrm{Ca}$ & $P$ & $\mathrm{Na}$ & $\mathrm{K}$ & $\mathrm{Mg}$ & $\mathrm{DMI}^{1}(\mathrm{~kg})$ \\
\hline \multicolumn{7}{|c|}{ Net requirement for gain $(\mathrm{g} / \mathrm{kg})$} \\
\hline 200 & 16.44 & 5.92 & 1.31 & 1.93 & 0.42 & \\
\hline 250 & 15.93 & 5.76 & 1.29 & 1.95 & 0.42 & \\
\hline 350 & 15.19 & 5.54 & 1.26 & 1.98 & 0.41 & \\
\hline 400 & 14.91 & 5.45 & 1.25 & 2.00 & 0.40 & \\
\hline 250 & 4.24 & 4.41 & 1.87 & 28.57 & 0.83 & \\
\hline 300 & 5.09 & 5.29 & 2.25 & 33.59 & 0.99 & \\
\hline 350 & 5.94 & 6.17 & 2.62 & 38.62 & 1.16 & \\
\hline 400 & 6.79 & 7.06 & 3.00 & 43.64 & 1.32 & \\
\hline \multicolumn{7}{|c|}{ Total net requirement (g/day) } \\
\hline 200 & 19.83 & 9.45 & 2.81 & 25.48 & 1.08 & \\
\hline \multicolumn{7}{|c|}{ Total net requirement (g/day) } \\
\hline 200 & 39.67 & 13.89 & 3.09 & 25.48 & 6.37 & \\
\hline 250 & 40.35 & 14.96 & 3.48 & 30.52 & 7.31 & \\
\hline 300 & 41.23 & 16.08 & 3.87 & 35.56 & 8.25 & \\
\hline 350 & 42.26 & 17.22 & 4.27 & 40.60 & 9.19 & \\
\hline 400 & 43.39 & 18.39 & 4.67 & 45.64 & 10.14 & \\
\hline Bioavailability ${ }^{2}$ & 0.50 & 0.68 & 0.91 & 1.00 & 0.17 & \\
\hline \multicolumn{7}{|c|}{ Dietary requirement (\%DM) } \\
\hline 200 & 0.81 & 0.28 & 0.06 & 0.52 & 0.13 & 4.91 \\
\hline 250 & 0.68 & 0.25 & 0.06 & 0.52 & 0.12 & 5.92 \\
\hline 300 & 0.60 & 0.23 & 0.06 & 0.51 & 0.12 & 6.92 \\
\hline
\end{tabular}

${ }^{1}$ DMI (dry matter intake) $(\mathrm{kg} /$ day $)=-2.40011+0.02006 \times$ BW (body weight $)+4.81946 \times$ Average daily gain $(\mathrm{ADG})-1.51758 \times \mathrm{ADG}^{2}$, equation proposed in BR-Corte, (Valadares Filho et al., 2006e).

2 References in Table 2, in Material and Methods.

EBW found by Sales et al. (2011), working with crossbred Nellore/Holstein animals.

Values of Mg decreased little as body weight increased -0.42 for $0.40 \mathrm{~g} / \mathrm{kg}$ of EBW -, which is very close to the one recommended by the ARC (1980), which allows constant Mg net requirement of $0.45 \mathrm{~g} / \mathrm{kg}$ EBW, regardless of animal weight.

The net requirements found in this study, for animals with 250 and $400 \mathrm{~kg} \mathrm{BW}$ were 1.29 and $1.25 \mathrm{~g} / \mathrm{kg}$ EBWG for $\mathrm{Na}$ and 1.95 and $2.00 \mathrm{~g} / \mathrm{kg}$ EBWG for K. The variation in body content of $\mathrm{Na}$ and $\mathrm{K}$ were only 0.06 and $0.07 \mathrm{~g} / \mathrm{kg}$ EBWG (Table 8). By presenting a small variation in the requirements, the ARC (1980) preconizes fixed net requirements of 1.50 and $2.0 \mathrm{~g} / \mathrm{kg}$ EBWG for $\mathrm{Na}$ and $\mathrm{K}$, respectively, which are close to those found in this study.

It was found that there was reduction for all macrominerals (\% of DM) on dietary requirements, and values were almost constant, $0.05,0.51$ and $0.12 \%$ of DM for $\mathrm{Na}, \mathrm{K}$ and $\mathrm{Mg}$ from $300 \mathrm{~kg}$ of BW, respectively, which is close to those recommended by the NRC (2000) and Valadares Filho et al. (2006c).

\section{Conclusions}

Daily requirements of metabolizable energy for maintenance of grazing crossbred Nellore/Holstein animals were $125 \mathrm{kcal} / \mathrm{kg} \mathrm{EBW}^{0.75}$. It is recommended to estimate the net energy requirements for weight gain of these animals by the equation $N E g=0.0414 \times E B W^{0.75} \times E B W G^{1.3034}$, $\left(\mathrm{R}^{2}=59.6\right)$. Use efficiency of metabolizable energy of grazing crossbred Nellore/Holstein animals is 0.58 for maintenance and 0.24 for gain. Net protein requirements for weight gain of grazing non-castrated crossbred Nellore/ Holstein, with up to $400 \mathrm{~kg}$ body weight can be estimated from the equation $R P g(g /$ day $)=-14.50320+2.38594 E R$ $($ Mcal/day $)+164.2072 E B W G(\mathrm{~kg} /$ day $),\left(\mathrm{R}^{2}=0.67\right)$. 


\section{References}

AGRICULTURAL AND FOOD RESEARCH COUNCIL - AFRC. A reappraisal of the calcium and phosphorus requirements of sheep and cattle. 6.ed. Nutrition Abstract and Reviews (Series B). Wallingford: 1991. p.573-612.

AGRICULTURAL RESEARCH COUNCIL - ARC. The nutrient requirements of ruminants livestock. London: Commonwealth Agricultural Bureaux, 1980. 351p.

BALDWIN, R.L. Modeling ruminant digestion and metabolism. London: Chapman and Hall, 1995. 592p.

BERG, R.T.; BUTTERFIELD, R.M. New concepts of cattle growth. 1.ed. Sydney: Sydney University Press, 1976. 240p.

BOIN, C. Alguns dados sobre exigências de energia e de proteína de zebuínos. In: SIMPÓSIO INTERNACIONAL SOBRE EXIGÊNCIAS NUTRICIONAIS DE RUMINANTES. Viçosa, MG. Anais... Viçosa, MG: Universidade Federal de Viçosa, 1995. p.457-466.

BROSH, A.; HENKIN, Z.; UNGAR, E.D. et al. Energy cost of cows grazing activity: Use of the heart rate method and the global Positioning System for direct field estimation. Journal Animal Science, v.84, p.1951-1967, 2006.

CASALI; A.O.; DETMANN; E.; VALADARES FILHO, S.C. et al. Influência do tempo de incubação e do tamanho de partículas sobre os teores de compostos indigestíveis em alimentos e fezes bovinas obtidos por procedimentos in situ. Revista Brasileira de Zootecnia, v.37, n.2, p.335-342, 2008.

CHIZZOTTI, M.L.; VALADARES FILHO, S.C.; TEDESCHI, L.O. et al. Energy and protein requirements for growth and maintenance of F1 Nellore x RedAngus bulls, steers, and heifers. Journal of Animal Science, v.85, p.1971-1981, 2007.

COELHO DA SILVA, J.F.; LEÃO, M.I. Fundamentos de nutrição de ruminantes. Piracicaba: Livroceres, 1979. 380p.

COELHO DA SILVA, J.F. Exigências de macroelementos inorgânicos para bovinos: o sistema ARC/AFRC e a experiência no Brasil. In: SIMPÓSIO INTERNACIONAL SOBRE EXIGÊNCIAS NUTRICIONAIS DE RUMINANTES, 1., 1995, Viçosa, MG. Anais... Viçosa, MG: Universidade Federal de Viçosa, 1995. p.467-504.

COMMONWEALTH SCIENTIFC AND INDUSTRIAL RESEARCH ORGANIZATION - CSIRO. Nutrient requeriments of domesticated ruminants. Victoria: Australia Agricultural Council, 2007. 270p.

DiMARCO, O.N.; AELLO, M.S. Energy expenditure due to forage intake and walking of grazing cattle. Arquivo Brasileiro de Medicina Veterinária e Zootecnia, v.53, n.1, p.105-100, 2001.

FERRELL, C.L.; JENKINS, T.G. Body composition and energy utilization by steers of diverse genotypes fed a high-concentrate diet during the finishing period: II. Angus, Boran, Brahman, Hereford, and Tuli sires. Journal of Animal Science, v.76, p.647-657, 1998.

FREGADOLLI, F.L. Composição corporal e exigências nutricionais de novilhos de três grupos genéticos em pastejo. 2005. 85f. Tese (Doutorado em Zootecnia) Universidade Estadual Paulista, Faculdade de Ciências Agrárias e Veterinárias, Jaboticabal.

GARRETT, W.N. Factors influencing energetic efficiency of beef production. Journal of Animal Science, v.51, n.6, p.1434-1440, 1980.

HANKINS, O.G.; HOWE, P.E. Estimation of the composition of beef carcasses and cuts. [T.B.]: United Sates Department of Agriculture, 1946. p.1-19 (Technical Bulletin - USDA, 926).

HALL, M.B. Calculation of non-structural carbohydrate content of feeds that contain non-protein nitrogen. University of Florida, 2000. p.A-25 (Bulletin 339, 2000).

LAZZARINI, I., DETMANN, E., SAMPAIO, C.B. et al. Intake and digestibility in cattle fed low-quality tropical forage and supplemented with nitrogenous compounds. Revista Brasileira de Zootecnia, v.38, n.10, p.2021-2030, 2009.

LICITRA, G.; HERNANDEZ, T.M.; VAN SOEST, P.J. Standardization of procedures for nitrogen fractionation of ruminant feeds. Animal Feed Science and Technology, v.57, p.347-358, 1996

LOFGREEN, G.P.; GARRETT, W.N.A. System for expressing net energy requeriments and feed values for growing and finishing beef cattle. Journal of Animal Science, v.27, n.3, p.793-806, 1968.

MERTENS, D.R. Gravimetric determination of amylase-treated neutral detergent fibre in feeds with refluxing beakers or crucibles: collaborative study. Journal of AOAC International, v.85, p.1217-1240, 2002.

MORAES, E.H.B.K.; PAULINO, M.F.; MORAES, K.A.K. et al. Exigências de energia de bovinos de corte em pastejo. Revista Brasileira de Zootecnia, v.38, n.5, p.933-940, 2009.

NATIONAL RESEARCH COUNCIL - NRC. Nutrient requirements of beef cattle. 7. rev. ed. Washington, D.C.: National Academic Press, 2000. 242p.

PAIXÃO, M.L. Desempenho produtivo e exigências nutricionais de bovinos de corte em pastagens de Brachiaria decumbens, com suplementação protéica. 2008. 128f. Tese (Doutorado em Zootecnia) - Universidade Federal de Viçosa, Viçosa, MG.

PAULINO, P.V.R; COSTA, M.A.L.; VALADARES FILHO, S.C. et al. Exigências nutricionais de zebuínos. Energia. Revista Brasileira de Zootecnia, v.33, n.3, p.781-791, 2004.

PAULINO, M.F.; DETMANN, E.; VALADARES FILHO, S.C. Suplementação animal em pasto: energética ou protéica?. In: Simpósio sobre manejo estratégico da pastagem, 3., 2006, Viçosa, MG. Anais... Viçosa, MG: SIMFOR, 2006a. p.359-392.

PAULINO, P.V.R.; VALADARES FILHO, S.C.; DETMANN, E. et al. Exigências nutricionais de Zebuínos no Brasil. I. Minerais. In: VALADARES FILHO, S.C.; PAULINO, P.V.R.; MAGALHÃES, K.A. (Org.). Exigências nutricionais de zebuínos e tabelas de composição de alimentos. BR-Corte. 1.ed. Visconde do Rio Branco: Suprema Gráfica Ltda., 2006b. p.85-94.

POPPI, D.P.; McLENNAN, S.R. Protein and energy utilization by ruminants at pasture. Journal of Animal Science, v.73, p.278-290, 1995.

REYNOLDS, C.K.; LAPIERRE, H.; TYRREL, H.F. et al. Effects of growth hormona-releasing factor and feed intake on energy metabolism in growing beef steers: net nutrient metabolism by portal-drained viscera and liver. Journal of Animal Science, v.70, p.752-769, 1992.

SAINZ, R.D.; BARIONI, L.G.; PAULINO, P.V.R. et al. Growth patterns of Nellore vs. British beed cattle breeds assessed using a dynamic, mechanistic model of cattle growth and composition. In: KEBREAB, E.; BANNINK, A.; GERRITS, W.J.J. et al. (Eds.) Nutrient digestion and utilization in farm animais: modeling approaches. 6.ed. Cambridge: Cabi Publishing, 2006. 480p.

SALES, M.F.L.; PAULINO, M.F.; VALADARES FILHO, S.C. et al. Níveis de uréia em suplementos múltiplos para terminação de novilhos em pastagem de capim-braquiária durante o período de transição águas-seca. Revista Brasileira de Zootecnia, v.37, n.9, p.1704-1712, 2008.

SALES, M.F.L. Desempenho e exigências nutricionais de novilhos zebuínos sob pastejo. 2008. 128f. Tese (Doutorado em Zootecnia) - Universidade Federal de Viçosa, Viçosa, MG.

SALES, M.F.L.; PAULINO, M.F.; VALADARES FILHO, S.C. et al. Exigências proteicas de bovinos de corte suplementados a pasto. Revista Brasileira de Zootecnia, v.39, n.9, p.2066-2072, 2010.

SALES, M.F.L.; PAULINO, M.F.; VALADARES FILHO, S.C. et al. Macromineral requirements by beef cattle under pasture supplementation. Revista Brasileira de Zootecnia, v.40, n.12, p.426-432, 2011. 
SILVA, D.J; QUEIROZ, A.C. Análise de alimentos (métodos químicos e biológicos). 3.ed. Viçosa, MG: Universidade Federal de Viçosa, 2002. 235p.

SILVA, F.F.; VALADARES FILHO, S.C.; ITAVO, L.C.V. et al. Exigências líquidas e dietéticas de energia, proteína e macroelementos minerais de bovinos de corte no Brasil. Revista Brasileira de Zootecnia, v.31, n.2, p.776-792, 2002.

SMITH, A.M.; REID, J.T. Use of chromic oxide as an indicator of fecal output for the purpose of determining the intake of a pasture herbage by grazing cows. Journal of Dairy Science, v.38, n.5, p.515-524, 1955.

TEDESCHI, L.O.; BOIN, C.; FOX, D.G. et al. Energy requirement for maintenance and growth of Nellore bulls and steers fed high-forage diets. Journal of Animal Science, v.80, n.6, p.1671-1682, 2002.

TITGEMEYER, E.C.; ARMENDARIZ, C.K.; BINDEL, D.J. et al. Evaluation of titanium dioxide as a digestibility marker for cattle. Journal of Animal Science. v.79, p.1059-1063, 2001.

VALADARES FILHO, S.C.V.; PAULINO, P.V.R; MAGALHÃES, K.A. Exigências nutricionais de zebuínos e tabelas de composição de alimentos BR-Corte. Viçosa, MG: UFV, DZO, 2006a. 142p.

VALADARES FILHO, S.C.; MORAES, E.H.B.K.; DETMANN, E. et al. Perspectivas do uso de indicadores para estimar o consumo individual de bovinos alimentados em grupo. In: REUNIÃO ANUAL DA SOCIEDADE BRASILEIRA DE ZOOTECNIA, 43., 2006. João Pessoa. Anais... João Pessoa: SBZ: UFPB, 2006b. v.35, p.291-322.

VALADARES FILHO, S.C.; PAULINO, P.V.R.; DETMANN, E. et al. Exigências nutricionais de zebuínos no Brasil. I. Energia. In: VALADARES FILHO; S.C.; PAULINO; P.V.R.; MAGALHÃES,
K.A. (Orgs.). Exigências nutricionais de zebuínos e tabelas de composição de alimentos. BR-Corte. Visconde do Rio Branco: Suprema Gráfica Ltda., 2006c. p.57-73.

VALADARES FILHO, S.C.; PAULINO, P.V.R.; VALADARES R.F.D. et al. Exigências nutricionais de Zebuínos no Brasil I. Proteína. In: VALADARES FILHO, S.C.; PAULINO, P.V.R.; MAGALHÃES, K.A. (Orgs.). Exigências nutricionais de zebuínos e tabelas de composição de alimentos. BR-Corte. Visconde do Rio Branco: Suprema Gráfica Ltda., 2006d. p.75-84.

VALADARES FILHO, S.C.; AZEVEDO, J.A.G.; PINA, D.S. et al. Consumo de matéria seca de bovinos nelore e mestiços. I. Consumo de matéria seca de bovinos nelore e mestiços. In: VALADARES FILHO; S.C.; PAULINO; P.V.R.; MAGALHÃES; K.A. (Orgs.). Exigências nutricionais de zebuínos e tabelas de composição de alimentos. BR-Corte. Visconde do Rio Branco: Suprema Gráfica Ltda., 2006e. p.1-12.

VALADARES FILHO, S.C.; MARCONDES, M.I.; CHIZZOTTI, M.L. et al. Exigências nutricionais de zebuínos puros e cruzados: BR-Corte. 2.ed. Viçosa, MG: Suprema Gráfica Ltda, 2010. 193p.

VANDERWERT, W.; BERGER, L.L; McKEITH, F.K. et al. Influence of zeranol implants on growth, behaviour and carcass traits in Angus and Limousin bulls and steers. Journal of Animal Science, v.61, p.310-319, 1985

VAN SOEST, P.J.; ROBERTSON, J.B. Analysis of forages and fibrous foods. Ithaca: Cornell University, 1985. 202p.

ZERVOUDAKIS, J.T.; PAULINO, M.F.; DETMANN, E. et al. Conteúdo corporal e exigências líquidas de proteína e energia de novilhos suplementados no período das águas. Revista Brasileira de Zootecnia, v.31, n.1, p.530-537, 2002. 